\title{
Penile fasciocutaneous flap urethroplasty in long segment urethral stricture
}

\author{
Ali Atan, M.D., ${ }^{1}$ Altuğ Tuncel, M.D., ${ }^{2}$ Melih Balcı, M.D.,, ${ }^{2}$ Yılmaz Aslan, M.D., ${ }^{2}$ \\ Ersin Köseoğlu, M.D., ${ }^{2}$ Anıl Erkan, M.D. ${ }^{2}$
}

${ }^{1}$ Department of Urology, Gazi University Faculty of Medicine, Ankara;

23rd Department of Urology Ankara Numune Training and Research Hospital, Ankara

\begin{abstract}
BACKGROUND: The aim of this study was to evaluate the succes of penil fasciocutaneous flap urethroplasty in the treatment of long segment urethral stricture.

METHODS: In this study, seventeen patients with long segment urethral stricture were included. In regard to the length of the narrow segment, vertical or circular penile skin fasciocutaneous flap was anastomosed on $18 \mathrm{~F}$ urethral catheter. In the first week and 6th month after removal of the urethral catheter, patients were controlled by uroflowmetry and postvoiding residual urine volume measurement by ultrasound.
\end{abstract}

RESULTS: The mean age of the patients was 52 (range: 17 to 67 years). The mean follow up-time was 60 months (range: $12-96$ months). Mean length of stricture was $105 \mathrm{~mm}$ (range: $40-150 \mathrm{~mm}$ ). Vertical and circular penile fasciocutaneous flaps were used in four and 13 patients, respectively. Maximum urine flow rate and postvoiding residual urine assessment in the first week after removal of the urethral catheter were $19.1 \mathrm{ml} / \mathrm{s}$ (range: 9 to $31 \mathrm{ml} / \mathrm{s}$ ) and $12.9 \mathrm{~cm}^{3}$ (range: 0 to $40 \mathrm{~cm}^{3}$ ), respectively. Same parameters in the postoperative 6th month were $17.4 \mathrm{ml} / \mathrm{s}$ (range; 8 to $25 \mathrm{ml} / \mathrm{s}$ ) and $15.2 \mathrm{~cm}^{3}$ (range; 0 to $40 \mathrm{~cm}^{3}$ ), respectively.

CONCLUSION: Our long term results revealed that penile fasciocutaneous flap urethroplasty method seemed to be a reasonable treatment option in the treatment of long segment urethral stricture.

Key words: Penil fasciocutaneous flap; success; treatment; urethroplasty.

\section{INTRODUCTION}

In recent years, endoscopic procedures with high technologies have occupied our daily urology practice. Urethroplasty is one of the last procedures to perform as an open surgery. Although most common etiologies for urethral stricture are blunt or sharp perineal trauma, urethral catheterization, urethral endoscopic procedures, lichen sclerosis, and sexually transmitted diseases, no exact cause can be found in some cases with urethral stricture. ${ }^{[1]}$

In selecting a treatment method for urethral strictures, the

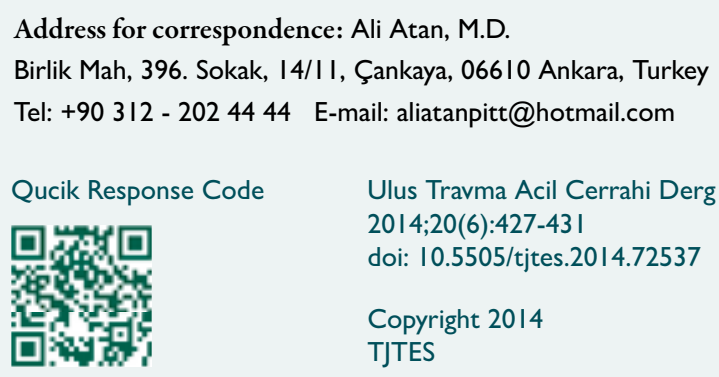

key points to consider are stricture length, location of stricture, and surgeon's preference and experience. Therefore, there is not a single, perfect technique for all patients with urethral stricture. There are many methods used for the treatment of urethral stricture including simple bougie dilatation, visual optic internal urethrotomy, laser urethrotomy, stent placement, balloon dilatation, endoscopic urethroplasty, primary anastomotic urethroplasty, and substitution urethroplasty with flaps and grafts. ${ }^{[2,3]}$

The treatment of long segment urethral strictures is a very challenging problem for urologists and patients as dilatation and visual urethrotomies do not provide long term success for these cases in general. Substitution urethroplasty with flaps or grafts will be the preferred treatment in these patients. However, there is no agreement in the selection of a flap or graft technique and in the ideal material of a flap or graft. There are many tissues including preputial and penile skin, scrotal skin, dermis, buccal and bladder mucosa, tunica vaginalis, deep fascia, peritoneum, small intestinal submucosa, appendix mucosa, and autologus vein proposed for urethral substitution. ${ }^{[4,5]}$ 
In the current study, long term results of the patients who underwent penil fasciocutaneous flap urethroplasty due to long segment urethral stricture were presented.

\section{MATERIALS AND METHODS}

A total of seventeen consecutive male patients with long segment urethral strictures admitted to our department between February 2005 and November 2012 were included in this study. At the time of admission, three patients had cystostomy and 14 had difficult urination. After taking detailed patient history, a careful physical examination involving genital, perineal and rectal regions was performed. Urine analysis, urine culture, and serum biochemical analysis including renal function tests were carried out. In patients without cystostomy, urine flow rate and postvoiding residual urine volume were measured. In order to detect the length and location of urethral stricture, retrograde urethrography using I/3 diluted contrast material (30 cc saline and $10 \mathrm{cc}$ Telebrix ${ }^{\circledR}$ [Guerbet Inc.]) was practiced in anterior-posterior and oblique positions. In patients with cystostomy, the bladder was filled with same amount of contrast material, the patients were asked to void and cystography was performed in order to detect proximal part of the stricture more clearly. If pyuria was found in urine analysis, urine culture was performed to isolate the responsible agent for the urinary tract infection. If no bacteria was isolated in urine culture in those patients, parenteral 3 rd generation cephalosporin was given for 3 days before surgery. If any bacteria was isolated in the culture, appropiate antibiotic therapy was given for at least 7 days. When control urine culture was negative, the patients underwent surgey.

\section{Surgical Technique}

Supine position was used when the urethral stricture was located in penile urethra. Dorsal lithotomy position was used if urethral stricture involved in the bulbar urethra. After appropiate positioning, lower abdominal, genital and perineal areas were scrubbed with povidion iodine for five minutes. After putting a traction suture in glans penis, strictured part of the urethra was opened until healthy urethral tissue (Fig. la). According to the length and location of the urethral stricture, ventral or circular penil fasciocutaneous flap was prepared (Figs. Ib and c). Width of the penil fasciocutaneous flap was between $15-20 \mathrm{~mm}$ with regard to urethral plate available. New urethra was created over $18 \mathrm{~F}$ urethral foley catheter with 5/0 Polydiaxanone sture under $\times 2.5$ magnification without tension (Fig. Id). Anastomotic area was covered by surrounding soft tissue. After careful hemostasis to avoid hematoma formation after surgery, a multilayer close was
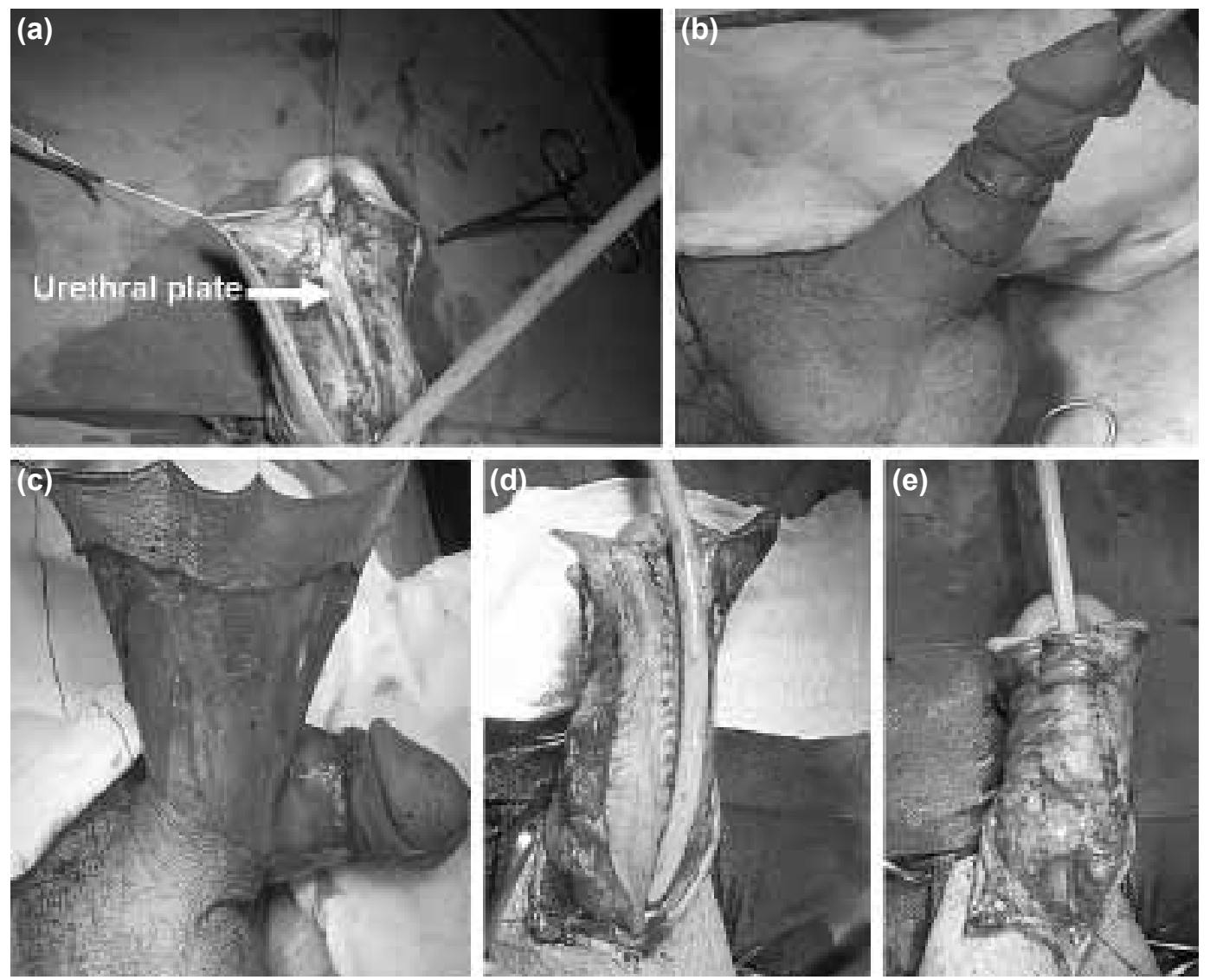

Figure 1. (a) Strictured part of the urethra opened until healthy urethral tissue. (b, c) Circumferential penil fasciocutaneous flap preparation. (d) Anastomotic urethroplasty with penil fasciocutaneous flap and urethra. (e) Anastomotic area is covered by surrounding soft tissue. 
performed (Fig. Ie). All operations were performed by one of the authors (A.A.).

Antibiotic treatment was given for 7 days in the postoperative period. Urethral foley catheter was left in place for 21 days. In the first week and 6th month after removal of the urethral catheter, all patients were controlled using uroflowmetry and postvoiding residual urine volume measurement by ultrasound. International Prostate Symptom Score (IPSS) was asked for the patients in the postoperative 6th month. The patients were controlled in each 6 months by same parameters. In patients with troubles in voiding, low urine rate less than $10 \mathrm{ml} / \mathrm{s}$, and postvoiding residual urine above $100 \mathrm{ml}$, retrograde urethrography and urethroscopy were performed.

\section{RESULTS}

The mean age of the patients was 52 (range: 17 to 67 years) Etiologic factors were pelvic bone fracture trauma in five (29.4\%), traumatic urethral catheterization in $4(23.6 \%)$, and urethral endoscopic surgery in 3 patients (17.6\%). No exact etiology was found in five of the patients (29.4\%). All patients were primarily operated and fourteen had previously undergone internal urethrotomies. In four patients with penile urethral stricture, surgery was performed in supine position; whereas in 13 patients with penile and bulbar urethra stricture, surgery was performed in dorsal lithotomy position.

The mean follow up-time was 60 months (12-96). The mean length of stricture was $105 \mathrm{~mm}$ (range: 40 to $150 \mathrm{~mm}$ ). Vertical and circular penile fasciocutaneous flaps were used in four and 13 patients, respectively. Mean operation time was 172 min (range: 90 to $140 \mathrm{~min}$ ). The mean maximum urine flow rate and postvoiding residual urine volume performed in the first week after removal of the urethral catheter were 19.1 $\mathrm{ml} / \mathrm{s}$ (range: 9 to $31 \mathrm{ml} / \mathrm{s}$ ) and $12.9 \mathrm{~cm}^{3}$ (range: 0 to $40 \mathrm{~cm} 3$ ), respectively. Same parameters mentioned above in the postoperative 6th month were $17.4 \mathrm{ml} / \mathrm{s}$ (range: 8 to $25 \mathrm{ml} / \mathrm{s}$ ) and $15.2 \mathrm{~cm}^{3}$ (range: 0 to $40 \mathrm{~cm}^{3}$ ), respectively. The mean IPSS performed in the 6th month after postoperative removal of the urethral catheter was 6.6 (range: 0 to 15).

No urinary tract and wound infections were seen in the postoperative period. In addition, urethrocutaneous fistula and wound dehiscence were not observed. Penile torsion and penile curvature did not occur in all patients.

In the long term period, stricture at anastomosis region was seen in three $(17.6 \%)$ patients. Stricture at anastomosis region in these patients occured in first 2 years. Internal urethrotomy was performed in two of the patients. Second look internal urethrotomy was necessary in one of them. The remaining one patient underwent re-urethroplasty. Those three patients have no difficulties in voiding now. In last control, all of the patients including those 3 patients have no difficulties in voiding now.

\section{DISCUSSION}

Substitution urethroplasty with flap and graft is performed by two methods: circumferential and patch substitution. While circumferential substitution performed by a tubularised flap or graft over a foley catheter has a low succes rate, patch substitution performed by an onlay/inlay flap or graft placement has a high success rate. ${ }^{[6]}$ Comparing graft and flap methods, both have the same success rates. ${ }^{[6-8]}$ Flap and graft could be placed in dorsal or ventral side of the urethra. In a meta-analysis, success rates of ventral and dorsal replacement have been found the same $(87.6 \%$ vs. $89.2 \%) .{ }^{[9]}$ Penile skin, prepitium and skrotal skin can be preperad as a flap. ${ }^{[10]}$ There are some important points in performing flap urethroplasty. Surgery should be performed with delicate surgical equipments using absorbable, fine suture material under magnification to avoid tissue trauma and impairment of blood supply in a well-lightened operation room. Suture lines should not be overlapped. Flap pedicle should have enough length in order not to create tension on suture lines. In order to avoid fistula formation and sacculation, a multilayer close should be performed. Hairless areas of the penile skin should be chosen for new urethra. The procedure should be completed in one stage. ${ }^{[10]}$ The advantages of penile fasciocutaneous flap urethroplasty are numerous, which include using well vascularized, hairless and flexible penile skin in repairement a long urethral segment up to $150 \mathrm{~mm}$, transfering easily to all parts of the urethra, being not costly, providing satisfactory results cosmetically, not destroying sexual functions, providing single stage repairement, and being suitable in some of previously circumcised men. ${ }^{[11-13]}$ While preparing penile fasciocutaneous flap, Buck fascia is usually kept to protect neurovascular structures under the Buck fascia. Flap pedicle delicately dissected to protect vascular supply of the flap should be mobilised sufficiently to transfer the flap to proximal part of the urethra and avoid penile torsion. In circular penile skin fasciocutanous flap urethroplasy, which is well described by McAninch and Morey, penile skin is cut from the ventral part. [II] In our patients, we preferred cutting the skin from the dorsal part, feeling that the flap was brought to the bulbar uretral area form the middle of the scrotum more easily.

Several studies have reported that the width of the flap may be changed from 15 to $25 \mathrm{~mm}$ according to the width of the urethral plate. ${ }^{[14-18]}$ Width of the flap more than $25 \mathrm{~mm}$ should not be used due to increased risk of urethral sacculation and diverticulum formation. ${ }^{[17]}$ Hence, a skin flap wider than 20 $\mathrm{mm}$ was not used. Urethral catheter, $16-18 \mathrm{~F}$ in size, was left in place between 14 and 21 days. ${ }^{[14,15,17,18]}$ Some authors prefer using cystostomy catheter with urethral catheter. ${ }^{[15-17]}$ In our patients, cystostomy catheter was never necessary. Only 18 $\mathrm{F}$ urethral catheter was used for $2 \mathrm{I}$ days.

In a study, ${ }^{[15]}$ penile skin flap urethroplasty $(n=19)$ was compared to penile skin graft $(n=18)$ urethroplasty. The mean length of urethral stricture was $141 \mathrm{~mm}$ in flap group and 
$152 \mathrm{~mm}$ in graft group. The mean follow up time was 37.1 and 36.2 months in flap and graft groups, respectively. In flap and graft groups, urethral stricture reccurrence was $21 \%$ and $27.7 \%$, respectively. The authors concluded that there was no difference between flap and graft urethroplasty methods in terms of success rate. In a study by Whitson et al., ${ }^{[19]}$ success rates of flap urethroplasty in the 5 th and 10 th years have been reported to be $84 \%$ and $79 \%$, respectively. In a recent study ${ }^{[14]}$ including thirty-six patients who underwent circular fasciocutanaous flap urethroplasty, the mean length of stricture was $60 \mathrm{~mm}$. The flap was placed in the ventral part of the urethra. The mean follow-up time was 96.7 months. According to the study, if patients had no urination problems with good voiding, surgery was considered successful. According to these criteria, success rate was over $90 \%$. Criteria for the failure of surgery were to re-start lower urinary tract symptoms, decrease urine flow rate, and re-stricture seen in urethrography. In the present study, the mean follow-up time was 60 months. The surgery of three patients in our study was a failure due to stricture recurrence. Single internal urethrotomy was sufficient in one patient and the other one patient required a second look internal urethrotomy. The remaining patient underwent re-urethroplasty. Our success rate is believed to be consistent with the international literature.

Penile/preputial island flap urethroplasty provides well-vascularised, versatile, and reliable tissue for urethral substitution. It ensures one-stage repair of strictures of the penile urethra with hairless tissue and maintains its pliability well with little postoperative constriction. Therefore, penile skin flap urethroplasty does not cause any penile shortness or curvarture. After wound healing, penile appearence is cosmetically satisfactory. The penile skin can transfer anywhere from the external meatus to the prostatic urethra for urethral reconstruction as a patch or tube. ${ }^{[13]}$ If the flap falls short, then it can be combined with other tissue transfer techniques, thus enabling one-stage reconstruction in majority of cases. ${ }^{[12]}$ Conversely, Andrich and Mundy have stated that the most reliable technique for long bulbar strictures is a patch augmentation with buccal mucosal graft, which may restore the narrowed urethral calibre to normal. ${ }^{[20]}$ In our patients, penil fasciocutaneous flap urethroplasy was preferred in patients with long segment urethral stricture. Our results are regarded to be very encouraging.

Contraindications of penile fasciocutaneous flap urethroplasty are insufficient penile skin and balanitis xerotica obliterans of the penis. ${ }^{[14,15]}$ In these patients, other tissues should be considered for reconstruction. In general, the complication rate of this surgery is reported between $8 \%$ and $20 \%$. Most common complications are scrotal and penile odemea, wound infection, urethrocutaneous fistula formation, stricture reccurrence, skin necrosis, penile torsion, postvoiding dribbling, urethral sacculation, and diveticulum formation. ${ }^{[14-16]}$ A recent prospective study by Olajide et al. ${ }^{[5]}$ was carried out with fifty-five patients with complex anterior urethral stricture to study complications of transverse distal penile island flap urethroplasty in a 6-year-period. The authors reported that infective complications were the commonest complication in their patients including wound infection in $9.1 \%$, urosepsis in $3.6 \%$, and epididymo-orchitis in $1.8 \%$ of the patients. In the present study, three (17.6\%) of the patients had re-stricture in anastomosis region. Apart from these complications, we did not confront wound infection, urethrocutaneous fistula, skin necrosis, penile torsion, postvoiding dribbling, urethral sacculation, and diverticulum formation.

Our long term results showed that penile fasciocutaneous flap urethroplasty seemed to be a reasonable treatment option in treatment of long segment urethral stricture with acceptable complication rate.

\section{Conflict of interest: None declared.}

\section{REFERENCES}

1. Goel A, Goel A, Jain A, Singh BP. Management of panurethral strictures. Indian J Urol 2011;27:378-84. CrossRef

2. Peterson AC, Webster GD. Management of urethral stricture disease: developing options for surgical intervention. BJU Int 2004;94:971-6.

3. Barbagli G, Lazzeri M. Surgical treatment of anterior urethral stricture diseases: brief overview. Int Braz J Urol 2007;33:461-9.

4. Vaos G, Gardikis S, Giatromanolaki A, Kambouri K, Trıpsianis G, Ypsilantis $\mathrm{P}$, et al. Long-term angiogenic activity of free grafts and pedicle flap in a rabbit urethroplasty model. World J Urol 2013;31:919-24. CrossRef

5. Olajide AO, Salako AA, Aremu AA, Eziyi AK, Olajide FO, Banjo OO. Complications of transverse distal penile island flap: urethroplasty of complex anterior urethral stricture. Urol J 2010 Summer;7:178-82.

6. Mundy AR. Management of urethral strictures. Postgrad Med J 2006;82:489-93. CrossRef

7. Wessells $\mathrm{H}, \mathrm{McAninch}$ JW. Current controversies in anterior urethral stricture repair: free-graft versus pedicled skin-flap reconstruction. World J Urol 1998;16:175-80. CrossRef

8. Hosseini J, Soltanzadeh K. A comparative study of long-term results of Buccal Mucosal Graft and Penile Skin Flap techniques in the management of diffuse anterior urethral strictures: first report in Iran. Urol J 2004 Spring;1:94-8.

9. Wang K, Miao X, Wang L, Li H. Dorsal onlay versus ventral onlay urethroplasty for anterior urethral stricture: a meta-analysis. Urol Int 2009;83:342-8. CrossRef

10. Doumanian LR. Evaluation and treatment of urethral stricture disease. Curr Bladder Dysfunct Rep 2010;5:198-204. CrossRef

11. McAninch JW, Morey AF. Penile circular fasciocutaneous skin flap in 1-stage reconstruction of complex anterior urethral strictures. J Urol 1998;159:1209-13. CrossRef

12. Dubey D, Kumar A, Bansal P, Srivastava A, Kapoor R, Mandhani A, et al. Substitution urethroplasty for anterior urethral strictures: a critical appraisal of various techniques. BJU Int 2003;91:215-8. CrossRef

13. Quartey JK. One-stage penile/preputial cutaneous island flap urethroplasty for urethral stricture: a preliminary report. J Urol 1983;129:284-7.

14. Schwentner C, Seibold J, Colleselli D, Alloussi SH, Gakis G, Schilling D, et al. Anterior urethral reconstruction using the circular fasciocutaneous flap technique: long-term follow-up. World J Urol 2011;29:115-20. CrossRef 
15. Hussein MM, Moursy E, Gamal W, Zaki M, Rashed A, Abozaid A. The use of penile skin graft versus penile skin flap in the repair of long bulbo-penile urethral stricture: a prospective randomized study. Urology 2011;77:1232-7. CrossRef

16. El Dahshoury ZM. Modified annular penile skin flap for repair of pananterior urethral stricture. Int Urol Nephrol 2009;41:889-94. CrossRef

17. Buckley J, McAninch J. Distal penile circular fasciocutaneous flap for complex anterior urethral strictures. BJU Int 2007;100:221-31. CrossRef
18. Carney KJ, McAninch JW. Penile circular fasciocutaneous flaps to reconstruct complex anterior urethral strictures. Urol Clin North Am 2002;29:397-409. CrossRef

19. Whitson JM, McAninch JW, Elliott SP, Alsikafi NF. Long-term efficacy of distal penile circular fasciocutaneous flaps for single stage reconstruction of complex anterior urethral stricture disease. J Urol 2008;179:2259-64.

20. Andrich DE, Mundy AR. What's new in urethroplasty? Curr Opin Urol 2011;21:455-60. CrossRef

\section{KLINIK ÇALIŞMA - ÖZET}

\section{Uzun segment üretral darlıklarda penil fasiyokutanöz flep üretroplasti \\ Dr. Ali Atan, ${ }^{1}$ Dr. Altuğ Tuncel, ${ }^{2}$ Dr. Melih Balcı, ${ }^{2}$ Dr. Yılmaz Aslan, ${ }^{2}$ Dr. Ersin Köseoğlu, ${ }^{2}$ Dr. Anıl Erkan ${ }^{2}$}

${ }^{1}$ Gazi Üniversitesi Tıp Fakültesi, Üroloji Anabilim Dalı, Ankara;

${ }^{2}$ Ankara Numune Eğitim ve Araştırma Hastanesi, 3. Üroloji Kliniği, Ankara

AMAÇ: Uzun segment üretral darlıklarda penil fasyokutanöz flep üretroplastinin başarısını incelemek.

GEREÇ VE YÖNTEM: Çalışmamıza uzun segment üretral darlığı olan 17 hasta alındı. Darlık segmentinin uzunluğuna göre, vertikal veya sirküler penil deri fasyokutanöz flep, $18 \mathrm{~F} \mathrm{üretral} \mathrm{kateter} \mathrm{üzerinden} \mathrm{anastomoz} \mathrm{edildi.} \mathrm{Hastalar,} \mathrm{üretral} \mathrm{kateterin} \mathrm{alınmasının} \mathrm{ardından} \mathrm{birinci} \mathrm{haftada} \mathrm{ve} \mathrm{altıncı} \mathrm{ayda}$ üroflovmetri ve ultrasonografi eşliğinde yapılan işeme sonrası rezidüel idrar hacmi ölçümleri ile değerlendirildi.

BULGULAR: Hastaların ortalama yaşı 52 ( I7-67) yıl, ortalama takip süresi 60 (I2-96) ay idi. Ortalama darlık uzunluğu I05 (40-I50) mm olarak saptandı. Vertikal ve sirküler penil fasyokutanöz flepler sırası ile dört ve 13 hasta için kullanıldı. Üretral kateterin alınmasının ardından birinci haftada yapılan maksimum idrar akım hızı ve işeme sonrası rezidüel idrar ölçümleri sırası ile $19.1(9-31) \mathrm{ml} / \mathrm{sn}$ ve $12.9(0-40) \mathrm{cm}^{3}$ idi. Aynı parametreler ameliyat sonrası altıncı ayda 17.4 (8-25) ve I5.2 (0-40) olarak ölçüldü.

TARTIŞMA: Uzun dönem sonuçlarımız penil fasyokutanöz flep üretroplastinin uzun segment üretral darlıklarda uygun bir tedavi seçeneği olduğunu göstermektedir.

Anahtar sözcükler: Üretroplasti; penil fasiyokutanöz flep; tedavi; başarı.

Ulus Travma Acil Cerrahi Derg 20 I4;20(6):427-43। doi: 10.5505/tjtes.20।4.72537 